\title{
PENGELOLAAN PROGRAM KEAKSARAAN USAHA MANDIRI DALAM MENINGKATKAN KEMAMPUAN BERWIRAUSAHA WARGA BELAJAR
}

(Studi Deskriptif pada kelompok belajar di SKB Kabupaten Cianjur tahun 2014)

\author{
Ahmad Ginanjar'), Uyu Wahyudin' ${ }^{2)}$, Asep Saepudin ${ }^{3)}$ \\ ${ }^{1)}$ Pengerak Seni Budaya dan Kewirausahaan Masyarakat di Kab. Cianjur \\ Dosen Departemen Pendidikan Luar Sekolah Fakultas Ilmu Pendidikan Universitas \\ Pendidikan Indonesia \\ Email: aspudin@gmail.com
}

\begin{abstract}
Issues addressed in this study is about the management of independent business literacy program in improving the ability of citizens to learn entrepreneurship. The purpose of this study was to describe: 1) Management of independent business literacy program in SKB Cianjur regency; 2) Ability to entrepreneurship learners in literacy programs, independent business in SKB Cianjur regency; 3) The factors supporting and literacy programs are independent business in SKB Cianjur regency. Respondents of this research 13 people. The method used in this research is descriptive method with qualitative research techniques. The results of this study found that: 1) The management of independent business literacy program in Cianjur regency SKB there are several stages: planning, implementation, and evaluation; 2) Ability to entrepreneurship learners in literacy programs, independent business in Cianjur district SKB that entrepreneurship skills in learners who take the program KUM seen from the characteristics of the learners themselves and how to take advantage of opportunities that exist. 3) The factors supporting and literacy programs are independent business in Cianjur district SKB is supporting factors in this program is on providing motivation to the participants given by tutors and managers so that people learn very enthusiastic about taking this KUM program.
\end{abstract}

Keywords : Management, Independent Business Literacy, Entrepreneurship

\section{A. PENDAHULUAN}

Program keaksaraan lebih dikenal dengan Program Pendidikan Keaksaraan Fungsional, sehingga secara terminologi (istilah) fungsional dalam keaksaraan, berkaitan erat dengan fungsi dan tujuan dilakukannya Pembelajaran di dalam program pendidikan keaksaraan, serta adanya jaminan bahwa hasil belajarnya benar-benar "bermakna/bermanfaat" atau fungsional bagi "peningkatan mutu dan taraf hidup" warga belajar dan masyarakatnya.
Pendidikan Keaksaraan Usaha Mandiri (KUM) merupakan lanjutan dari keaksaraan dasar yang dimaksudkan untuk memberikan penguatan keberaksaraan agar warga belajar yang sudah mengikuti (pasca program) pendidikan keaksaraan dasar tidak kembali buta aksara, dengan penekanan peningkatan keterampilan atau berusaha (kewirausahaan), sehingga dapat memiliki mata pencaharian dan penghasilan dalam rangka peningkatan taraf hidupnya. Program Keaksaraan Usaha Mandiri (KUM) merupakan kegiatan peningkatan kemampuan keberaksaraan bagi 
warga belajar yang telah mengikuti dan atau mencapai kompetensi keaksaraan dasar, melalui pembelajaran keterampilan usaha (kewirausahaan) yang dapat meningkatkan produktivitas warga belajar, baik secara perorangan maupun kelompok sehinggga diharapkan dapat memiliki mata pencaharian dan penghasilan dalam rangka peningkatan taraf hidupnya.

Tujuan dari keaksaraan fungsional diantaranya yaitu menuntaskan angka buta aksara di kalangan masyarakat Indonesia, meningkatkan pengetahuan membaca, menulis, dan berhitung serta keterampilan fungsional untuk meningkatkan taraf hidup masyarakat. Selain itu, tujuan dari keaksaraan yaitu untuk menggali potensi dan sumber-sumber kehidupan yang ada di lingkungan masyarakat.

Program Keaksaran Usaha
Mandiri ini bertujuan untuk
meningkatkan kemampuan usaha
mandiri dan mengaktualisasi
berbagai potensi yang dimiliki warga
belajar, selain itu program ini juga
bertujuan untuk mengembangkan
pengtahuan, sikap, keterampilan, dan
berwirausaha secara mandiri.

Kemampuan berwirausaha sangat diperlukan oleh masyarakat dalam memenuhi kebutuhan hidupnya. Dengan kemandirian atau kemampuan berwirausaha yang dimiliki oleh masyarakat, akan mejadikan masyarakat lebih mandiri dalam menciptakan lapangan kerja, tidak bergantung pada pemerintah maupun pihak lainnya. Dalam mewujudkan peningkatan kemampuan berwirausaha masyarakat, perlu diadakannya program pendidikan dan pemberian pengetahuan kewirausahaan kepada masyarakat, baik itu melalui program pemerintah maupun program swadaya.

Upaya meningkatkan Kualitas Sumber Daya Manusia (SDM) Indonesia serta meningkatkan kesejahteraan masyarakat, Pemerintah terus berupaya meningkatkan kuantitas dan kualitas pelaksanaan pendidikan baik formal mapun non formal, salah satu kegiatan yang telah dilaksanakan adalah kegiatan Program Keaksaraan Fungsional tahap pemberantasan yang dilaksanakan oleh Sanggar Kegiatan Belajar (SKB) di setiap wilayah.

SKB (Sanggar Kegiatan Belajar) kabupaten Cianjur merasa terpanggil dalam penanggulangan pemberantasan buta aksara dan mengembangkan kewirausahaan masyarakat. Kesadaran dan tanggung jawab pusat kegiatan belajar masyarakat terhadap pemberantasan buta aksara dan pengembangan kewirausahaan masyarakat ditunjukan melalui realisasi visi dari pusat kegiatan masyarakat, untuk menanggulangi permasalahan yang berhubungan dengan rendahnya tingkat kesadaran, kemauan dan kemampuan masyarakat dalam bidang pendidikan sehingga berdampak pada lemahnya perekonomian masyarakat.

Melihat keadan di lapangan berkaitan erat dengan permasalahan masyarakat buta aksara dan rendahnya perekonomian masyarakat yang banyak menimbulkan dampak tidak baik dalam keberlangsungan pembanguanan pendidikan dan ekonomi, dalam ruang lingkup 
khusus ketidak mampuan membaca, menulis dan berhitung ini menyebabkan ketidak optimalan dalam mengeksploitasi potensi yang dimiliki setiap individu yang di klasifikasikan buta aksara. Mereka memiliki keterbatasan dalam dinamika sosial, teknologi dan informasi. Dalam ruang lingkup umum buta aksaraan menyebabkan ketertinggalan bangsa ini dalam mempersiapkan diri menghadapi era globalisasi yang sarat dengan kompetisi, sehingga SKB Kabupaten Cianjur ini berinisiatif untuk menyelenggarakan dan merancang program Keaksaraan Usaha Mandiri sebagai wadah untuk menyalurkan kemampuan, kreatifitas masyarakat dan menuntun masyarakat untuk berwawasan tinggi dan mandiri dalam berwirausaha.

Salah satu lembaga Pendidikan Nonformal yang mengembangkan program Keaksaraan Usaha Mandiri (KUM) adalah SKB kabupaten Cianjur. Berdasarkan hasil identifikasi yang telah dilaksanakan oleh pihak SKB Kabupaten Cianjur, maka di terpilihlah tempat untuk pengelolaan program Keaksaraan Usaha Mandiri (KUM), yaitu salah satunya di Kampung Pasir Jengkol I, Kabupaten Cianjur. Sanggar Kegiatan Belajar Kabupaten Cianjur dilingkungannya masih terdapat warga masyarakat yang memiliki status buta aksara dan ekonomi lemah. Sehingga dipandang perlu untuk menyelenggarakan program Keaksaraan Fungsional 1 (satu) dan dilanjutkan dengan Keaksaraan Fungsional Usaha Mandiri (KUM). Maka dari itu salah satu tujuan diadakanya program keaksaraan usaha mandiri guna memberikan motivasi dan meningkatkan kemampuan berwirausaha warga belajar di lingkungan masyarakat.

Masyarakat di wilayah tersebut sangat berpotensi dalam pengembangan program ini, karena tingkat antusias masyarakat untuk meningkatkan kemampuan berwirausahanya sangat tinggi, dan juga didorong oleh keterampilan yang dimiliki masyarakat dapat dikembangkan. Namun pelaksanaan program keaksaraan usaha mandiri belum dikelola secara baik, sehingga membuat minimnya narasumber dalam keterampilan yang ada dimasyarakat tersebut. Berdasarkan alur pemikirandiatas, fokus kajian ini diarahkan untuk untuk mengetahui: (1) Mengetahui pengelolaan program keaksaraan usaha mandiri di SKB Kabupaten Cianjur,

Mendeskripsikan kemampuan berwirausahaan warga belajar dalam program keaksaraan usaha mandiri di SKB Kabupaten Cianjur, dan (3) Mengetahui faktor pendukung dan penghambat pada program keaksaraan usaha mandiri di SKB Kabupaten Cianjur.

\section{B. KAJIAN LITERATUR}

Teori yang menjadi rujukan dalam penyusunan penelitian ini yaitu konsep keaksaraan usaha mandiri menurut Menurut Direktorat Pendidikan Masyarakat (2010, hlm. keaksaraa usaha mandiri adalah kegiatan peningkatan kemampuan keberaksaraan melalui pembelajaran keterampilan usaha yang dapat meningkatkan produktivitas perorangan maupun kelompok secara mandiri bagi peserta didik yang telah 
mengikuti dan/atau mencapai kompetensi keaksaraan dasar.

kewirausahaan menurut Suryana (2006, hlm.2) mendefinisikan kewirausahaan (enterpreneurship) adalah kemampuan kreatif dan inovatif yang dijadikan dasar, kiat, dan sumber daya untuk mencari peluang menuju sukses.

Menurut Sudjana (2004:57) menjelaskan secara terminologis tentang pengertian pengelolaan program yaitu, "Sesuai dengan fungsi Manajemen Program, dalam pengelolaan program, terdapat beberapa tahapan kegiatan yang saling berkaitan, yaitu perencanaan, pelaksanaan, evaluasi."

Menurut Sudjana (2007, hlm. 259) mengungkapkan faktor pendukung dan penghambat dari pelatihan ini dapat diukur dengan menggunakan analis SWOT (Strengths, Weaknesses, Opportunities And Threats) atau kekuatan, kelemahan, peluang dan tantangan.

\section{METODE PENELITIAN}

Metode yang digunakan saat penelitian menggunakan metode kualitatif dan menggunakan studi deskriptif. Peneliti menggunakan pendekatan kualitatif karena memiliki pemikiran dasar bahwa pendekatan tersebut sesuai dengan fokus penelitian dalam memperoleh informasi pada objek penelitian atau gambaran mengenai pengelolaan program keaksaraan usaha mandiri dalam meningkatkan kemampuan berwirausaha warga belajar di SKB kabupaten Cianjur. Menurut Zainal Arifin (2012, hlm.29) pendekatan kualitatif merupakan : Penelitian untuk menjawab permasalahan yang memerlukan pemahaman secara mendalam dalam konteks waktu dan situasi yang bersangkutan, dilakukan secara wajar dan alami sesuai dengan kondisi objektif di lapangan tanpa manipulasi, serta jenis data yang dikumpulkan terutama data kualitatif. Proses penelitian yang dimaksud antara lain melakukan pengamatan terhadap orang dalam kehidupannya sehari-hari. Berinteraksi dengan mereka dan berupaya memahami bahasa dan tafsiran mereka tentang dunia sekitarnya. Untuk itu, peneliti harus terjun ke lapangan dengan waktu yang cukup lama.

Lokasi penelitian adalah SKB kabupaten Cianjur. Pertimbangan peneliti melaksanakan penelitian di wilayah ini karena masih diwilayah tempat tinggal, agar dapat membantu mendapatkan data secara cepat, tepat dan akurat sehingga dapat memperoleh data yang objektif. Subjek penelitian dalam penelitian ini ditentukan secara purposive, artinya subjek penelitian sebagai sumber data dipilih dengan pertimbangan tertentu. Subjek dalam penelitian ini adalah pihak yang terlibat dalam program KUM untuk meningkatkan kompetensi berwirausaha di SKB kabupaten Cianjur. Subjek penelitian disini berjumlah satu orang pengelola, dua orang tutor dan 10 orang warga belajar.

Peneliti mengumpulkan segala bentuk informasi yang diperoleh dari sumber informasi (informan). Teknik pengumpulan data merupakan langkah yang dapat membantu untuk memperoleh data dalam penelitian. Teknik pengumpulan data dalam 
penelitian ini diantaranya sebagai berikut:

\section{Studi Dokumentasi}

Menurut Arikunto (2013, hlm. 274) metode dokumentasi adalah mencari data mengenai hal-hal atau variabel yang berupa catatan, transkip, buku, surat kabar, majalah, prasasti, notulen, rapat, legger, agenda dan sebagainya. Studi dokumentasi merupakan usaha penelaahan terhadap beberapa dokumen atau arsip dari kegiatan keaksaraan usaha mandiri. Penggunaan studi dokumentasi dalam penelitian ini guna melengkapi data yang tidak dapat diperoleh melalui wawancara dan observasi. Cara ini digunakan untuk mendapatkan data-data yang berhubungan dengan pelaksanaan kegiatan keaksaraan usaha mandiri. Dokumen yang digunakan dalam penelitian ini seperti data-data lulusan atau alumni SKB Kabupaten Cianjur ,foto kegiatan pembelajaran dan profil SKB Kabupaten Cianjur.

2. Observasi

Penelitian ini peneliti menggunakan observasi partisipatif untuk mengumpulkan data yang berkenaan dengan kegiatan melalui kegiatan keaksaraan usaha mandiri SKB Kabupaten Cianjur. Dalam observasi partisipatif ini, peneliti terlibat dalam proses pembelajaran dan hasil yang didapat oleh orang yang sedang diamati atau yang digunakan sebagai sumber data penelitian, yaitu peneliti ikut langsung dalam melakukan observasi langsung terhadap mengamati dan melihat secara langsung bagaimana pelaksanaan, perencaan, serta evaluasi dari kegiatan keaksaraan usaha mandiri SKB Kabupaten
Cianjur. Selain itu untuk melihat dampak dari kegiatan keaksaraan usaha mandiri tersebut.

3. Wawancara

Wawancara merupakan teknik pengumpulan data dengan cara melakukan tanya-jawab secara langsung antara peneliti dengan sumber data. Teknik pengumpulan data dengan wawancara yang dilakukan oleh peneliti adalah wawancara terstruktur karena peneliti telah membuat instrumen penelitian berupa pedoman wawancara. Teknik ini juga digunakan oleh peneliti untuk mengumpulkan data tentang proses keaksaraan usaha mandiri, serta hasil dari kegiatan keaksaraan usaha mandiri. Alat yang digunakan adalah pedoman wawancara yang dibuat sesuai indikator.

Informan yang diwawancarai dalam penelitian ini adalah pengelola lembaga, tutor, serta lulusan atau alumni peserta didik keaksaraan usaha mandiri. Wawancara dilakukan satu kali kepada sumber data dengan estimasi waktu 60 menit dengan catatan apabila ada data yang belum terpenuhi peneliti akan melakukan wawancara kembali kepada sumber data.

4. Triangulasi Data

Triangulasi adalah mengecek sebuah kebenaran data yang diperoleh serta untuk meningkatkan pemahaman penelitian mengenai apa yang telah peneliti peroleh kemudian peneliti dapat membandingkannya baik dari sumber maupun tekniknya. Susan Stainback (1988) dalam Sugiyono (2008, hlm.330) menyatakan bahwa tujuan dari triangulasi bukan untuk mencari kebenaran tentang beberapa 
fenomena, tetapi lebih pada peningkatan pemahaman peneliti terhadap apa yang telah ditemukan.

Dalam teknik pengumpulan data, triangulasi diartikan sebagai teknik pengumpulan data yang bersifat menggabungkan dari berbagai teknik pengumpul data dan sumber data yang telah ada. Penelitian ini mengumpulkan data dengan triangulasi, peneliti mengumpulkan data yang menguji kredibilitas data dengan berbagai teknik pengumpulan data dari berbagai sumber data. Dengan triangulasi peneliti menggunakan observasi partisipatif, wawancara mendalam, dan dokumentasi untuk sumber data yang sama secara serempak. Sampai data yang diperoleh peneliti jenuh atau data yang dungkap hasilnya sama.

\section{HASIL PENELITIAN DAN PEMBAHASAN}

\section{Pengelolaan Program Keaksaraan Usaha Mandiri di SKB Kabupaten Cianjur}

perencanaan program KUM perlu dilakukan Identifikasi kebutuhan belajar, identifikasi karakter warga belajar, analisis program/kurikulum pembelajaran, dan perumusan tujuan pembelajaran. Tahap identifikasi dilakukan bertujuan untuk mengetahui kebutuhan belajar masyarakat, analisis karakteristik warga belajar bertujuan untuk mengetahui apakah warga belajar program KUM sudah memiliki SUKMA atau tidak. Analisi kurikulum yang dilakukan di SKB Kabupaten Cianjur yaitu kurikulum yang digunakan berasal dari pusat namun disesuaikan dengan hasil kebutuhan warga belajar dan sumber daya yang ada, baik sumber daya manusia atau sumber daya nonmanusia.

pelaksanaan program. Aspekaspek dalam pelaksanaan program terangkum dalam beberapa tahapan yaitu strategi pelatihan, metode pelatihan, media pelatihan, bahan ajar, fasilitator, sarana dan prasarana.Materi pembelajaran disusun dengan menggunakan pendekatan partisipatif. Artinya materi pembelajaran yang dirancang menitikberatkan pada bahan belajar yang bertujuan untuk pembentukan, perubahan, serta pematangan sikap dan perilaku peserta pelatihan.Metode yang digunakan ini sudah tepat karena penggunaan metode tersebut disesuaikan dengan penyampaian materi yaitu teori menggunakan metode ceramah, ketika penerapan aplikasi menggunakan metode praktek dengan peserta didik mempraktekan sesuai dengan perintah, dan dalam metode diskusi ditunjukan jika ada tugas atau materi yang harus didiskusikan dengan teman dan jika ada materi yang kurang dipahami maka dapat menggunakan metode diskusi. Media yang digunakan dalam pembelajaran secara teori dan praktek adalah modul, dalam praktek adanya bahan-bahan kue, buku-buku resep, dan alat membuat kue.

Evaluasi yang dilakukan oleh tutor terhadap warga belajar melalui tes praktek atau ujian praktek yang dinilai oleh tutor, selain ujian praktek adapula tes tulis dimana warga belajar diberikan soal yang harus diisi kemudian dinilai. Kegiatan evaluasi ini dilakukan diawal proses pembelajaran dan diakhir 
pembelajaran karena untuk mengukur sejauh mana warga belajar dapat menyerap materi yang telah disampaikan berupa pengetahuan dan keterampilan. Namun untuk evaluasi resmi adanya ujian akhir dimana materi telah selesai diberikan.

\section{Kemampuan Berwirausahaa Warga Belajar Dalam Program Keaksaraan Usaha Mandiri di SKB Kabupaten Cianjur}

Hasil lapangan menunjukkan bahwa kemampuan berwirausaha dilihat dari karakteristik warga belajar dan peluang yang mampu di peroleh warga belajar. Kemampuan berwirausaha warga belajar dapat dilihat dari karakteristik warga belajar. Karakteristik yang dimiliki oleh warga belajar dapat dilihat oleh tutor dan pengelola saat keikutsertaan warga belajar dalam proses pembelajaran program KUM serta usaha yang akan dilakoninya. Warga belajar mengikuti program KUM adalah karena faktor ekonomi dan adanya KBU, dengan adanya program KUM ini dapat membantu warga belajar untuk merubah keadaan menadi lebih baik dimasa depan. Dalam program KUM ini tutor melihat warga belajar memiliki kepercayaan yang tinggi dalam membuka usaha, hal tersebut dibuktikan saat proses pembelajaran berlangsung dimana warga belajar selalu berperan aktif hingga terjadinya komunikasi yang bagus. Kepemimpinan yang bagus dimiliki oleh warga belajar karena mereka dapat memimpin dirinya sendiri terlebih dahulu dengan memanage waktu belajar mereka sehingga tidak bentrok dengan kegiatan pribadi warga belajar.
Pembelajaran program KUM ini warga belajar diajarkan menjadi wirausaha hingga bagaimana cara memasarkan produk, dari warga belajar tidak bisa menjadi bisa. Produk yang diajarkan salah satu yang menonjol adalah membuat kue kering dan kue basah, kemudian kue tersebut dapat dijual oleh warga belajar. Kue basah dan kering selalu dijual dipasar tradisional, dititip di warung atau pembeli datang kerumah. Namun kue kering selalu kebanjiran orderan saat mendekati hari raya idul fitri.

Pembelajaran program KUM menuntut warga belajar berperan aktif agar warga belajar mendapatkan manfaat yang serius setelah mengikuti program KUM ini. Warga belajar diajarkan selalu bertanggung jawab terhadap tugas yang diberikan oleh tutor maupun pengelola agar nantinya mereka dapat menyelesaikan.

\section{Faktor Pendukung dan Penghambat Pada Program Keaksaraan Usaha Mandiri di SKB Kabupaten Cianjur}

a. Kekuatan

Pelaksanaan program KUM adanya keterbukaan mengenai kesulitan yang dihadapi dalam program KUM. Warga belajar tidak segan mengungkapkan jika mengalami kesulitan dalam kegiatan pembelajaran berlangsung, dan kesulitan tersebut diselesaikan bersama. Selain itu pemberian motivasi kepada peserta yang diberikan oleh tutor dan pengelola sehingga peserta sangat antusias mengikuti program KUM ini. Pemberian motivasi tersebut dengan cara tutor dan pengelola 
menyediakan fasilitas yang
dibutuhkan dibutuhkan dalam proses pembelajaran yang telah dilakukan. Program KUM menghasilkan produk yang beraneka ragam seperti kue basah dan kue kering. Kemudian banyak mitra pasar yang berminat membeli produk yang dihasilkan oleh program KUM yang dilaksanakan oleh SKB Kabupaten Cianjur. Dalam pelaksanaannya juga program KUM sangat di dukung oleh masyarakat lingkungan sekitar SKB.

b. Hambatan

Kegiatan program KUM yang dilaksanakan di SKB Kabupaten Cianjur masih ada beberapa hammbatan yang dirasakan yaitu dalam pemasaran, selalu ada mitra usaha yang tidak membayar produk langsung setelah produk dikirim. Biasanya mitra usaha tersebut membayar seminggu setelah produk dikirim, serta mitra usaha yang selalu menginginkan produk yang bagus, tapi dengan harga murah.

\section{c. Peluang}

Program KUM terbantu dengan dukungan masyrakat sekitar SKB Kabupaten Cianjur. Selain itu keaktifan dan keterlibatan warga belajar mendorong program KUM tersebut tetap berjalan. Program KUM yang dijalankan juga membuka peluang usaha untuk warga belajar dalam program KUM setelah tamat.

d. Ancaman

Terdapat beberapa ancaman dalam pelaksanaan kegiatan program KUM di SKB Kabupaten Cianjur, diantaranya pesaing yang menawarkan harga murah, kepada mitra usaha akan berdampak pada kerjasama yang sudah di jalin dengan SKB Kabupaten Cianjur. Selain itu warga belajar yang tidak semua hadir dalam proses pembelajaran tersebut, tidak hanya itu beberapa dari warga belajar tidak mengikuti pembelajaran tersebut secara tuntas ditakutnya perubahan yang terjadi tidak menyeluruh. Itu menyebabkan warga belajar menjadi tidak mandiri, sehingga tutor dan pengelola harus memberikan pengarahan lebih kepada warga belajar yang belum mandiri.

\section{E. KESIMPULAN DAN REKOMENDASI}

\section{Kesimpulan}

Sesuai dengan fungsi manajemen program, dalam pengelolaan program terdapat beberapa tahapan kegiatan yang saling berkaitan, yaitu perencanaan, pelaksanaan dan evaluasi. Perencanaan program KUM menggunakan strategi perencanaan bottom-up pengelola melakukan identifikasi terlebih dahulu dan mengetahui kebutuhan warga belajar dalam mengikuti kegiatan program KUM. Pelaksanaan dalam kegiatan program KUM ini menggunakan pendekatan pembelajaran partisipatif serta, metode pelatihan yang digunakan dalam program KUM yaitu ceramah, praktek dan diskusi. Media yang digunakan saat proses pembelajaran berlangsung adalah modul, dalam praktek adanya bahanbahan kue, alat masak kue, serta buku panduan membuat kue. Evaluasi yang dilakukan dalam program KUM ini yaitu dilakukan melalui tes tulisan dan praktek atau ujian praktek yang dinilai oleh tutor dan pengelola. Pelaksanaan evaluasi dilakukan saat mulai pembelajaran dan setelah pembelajaran. 
Kemampuan berwirausaha pada warga belajar yang mengikuti program KUM dilihat dari karakteristik warga belajar itu sendiri dan bagaimana cara mengambil peluang yang ada. Melihat karakteristik warga belajar dilihat saat proses awal yaitu wawancara dan saat proses pembelajaran berlangsung. serta usaha yang akan dilakoninya. Warga belajar mengikuti program KUM adalah karena faktor ekonomi dan adanya $\mathrm{KBU}$, dengan adanya program KUM ini dapat membantu warga belajar untuk merubah keadaan dan membantu keluarga berwirausaha.

Hal-hal yang membantu dalam program KUM yaitu adanya keterbukaan jika ada kesulitan yang dihadapi warga belajar dalam pelaksanaan program KUM, koperasi yang dikelola dengan baik, sehingga mampu menciptakan usaha secara mandiri, dukungan dari lembaga pendidikan sebagai upaya membantu program KUM, masyarakat yang memberi dukungan partisipasi kegiatan. Beberapa faktor penghambat berdasarkan informasi di lapangan yaitu, masih kurangnya pemasaran produk yaitu mitra usaha yang tidak membayar tunai saat produk dikirim, mitra usaha yang selalu menginnginkan produk bagus akan tetapi dengan harga yang murah.

\section{Rekomandasi}

Saran bagi Pengelola SKB adalah perlu adanya perbaikan dan peningkatan dalam hal sarana dan prasrana. Untuk saat ini sarana dan prasarana sudah mencukupi, namun akan lebih baik adanya peningkatan agar kegiatan pembelajaran berjalan kondusif. Selain itu harus lebih baik lagi dalam hal mensosialisasikan program KUM karena masih banyak masyarakat sekitar SKB yang masih rendah akan motivasi belajar. SKB Kabupaten Cianjur harus bisa menjalin kemitraan sebanyak mungkin dengan pihak lain agar produk yang sudah dihasilkan oleh warga belajar tidak sulit untuk dipasarkan. Bahan keterampilan yang diajarkanpun diharapkan berasal dari potensi sumber daya alam yang ada agar produk keterampilan yang dihasilkan mempunyai ciri khas dan unik.

Saran untuk pihak tutor adalah lebih meningkatkan motivasi belajar, tutor harus terus memotivasi dan membimbing warga belajar agar dalam peningkatan motivasi terjaga dengan baik sehingga tujuan dalam proses pembelajaran dapat tercapai sesuai dengan yang diharapkan. Pengarahan, kesabaran, sikap, dan tutur kata yang baik menjadi modal yang diperlukan oleh instruktur agar menjadi panutan bagi warga belajar.

\section{F. REFERENSI}

Arifin, Zainal. (2012). Penelitian Pendidikan - Metode dan Paradigma Baru. Bandung: PT. Remaja Rosdakarya.

Arikunto, S. (2013). Prosedur Penelitian Suatu Pendekatan Praktik. Jakarta: Rinerka Cipta

Direktorat Pendidikan Masyarakat. (2010). Acuan Penyelenggaraan dan Pembelajaran Keaksaraan Usaha Mandiri. Jakarta: 
Direktorat Jenderal

Pendidikan Nonformal dan Informal

Sudjana. (2007). Strategi

Pembelajaran Dalam

Pendidikan Luar Sekolah.

Bandung: Nusantara Press

$\begin{array}{cc}\text { Program } & \text { (2004). } \\ \text { Bandung: Fallah Production } & \text { Pendidikan }\end{array}$

Sugiyono, (2008). Metode Penelitian

Kuantitatif Kualitatif Dan

$R \& D$. Bandung: Alfabeta

Suryana, (2006). Kewirausahaan Pedoman Praktis: Kiat dan Proses Menuju Sukses, Edisi Ketiga, Penerbit Salemba, Jakarta 